Feature Article

\title{
Are Green Jobs Sustainable for Sri Lankan Economy?
}

\author{
M. Jayaweera ${ }^{*}$, J. Manatunge ${ }^{1}$ and A. Witharana ${ }^{1}$ \\ Department of Civil Engineering, University of Moratuwa, Moratuwa, Sri Lanka
}

\section{Introduction}

It is imperative that Sri Lanka grasps the concepts of green jobs to meet the most vital but intricate challenge of the $21^{\text {st }}$ Century, which is the transformation to a sustainable and a low-carbon economy. Such a transformation or a paradigm shift, which can be gradual or rapid depending on the circumstances, will undoubtedly have a considerable positive effect on the way we produce and/or consume goods and services. The speed at which this transformation would occur is likely to accelerate in the near future as there is a trend of global transition from a traditional to a low-carbon economy, in order to attain sustainable economies. Such trends will help create an array of different forms of green jobs across many sectors, and most probably can become a catalyst for further development. The International Labour Organization (ILO) has defined green jobs as "Jobs created when they help in reducing the negative environmental impacts ultimately leading to environmentally, economically and socially sustainable enterprises and economies". Green jobs, in general, stand on two pillars: decent work and environmental sustainability. Thus, green jobs can be defined as decent work that contributes to environmental sustainability. In a broader sense decent work needs to address the core of international labour standards such as freedom of association and effective recognition of the right to collective bargaining, elimination of all forms of forced or compulsory labour, effective abolition of child labour, elimination of discrimination in respect of employment and occupation, occupational health and safety, etc. whilst aligning to laws applicable to Sri Lanka. Environmental sustainability addresses issues such as effectively combating climate change, pollution prevention and control, conservation of eco-systems and biodiversity etc. (ILO, 2007).

\section{Survey on Green Job}

Green job surveys have been done by institutions in different countries such as Malaysia, Bangladesh, Australia, USA and elsewhere (UNEP, 2008). However, there is no comprehensive study undertaken up to now in order to find out the status of green jobs in practice in Sri Lanka. The main purpose of this green job survey in Sri Lanka was therefore to explore the role of organizations in three sectors (Agriculture, Industry and Services) in contributing towards green jobs opportunities while emphasizing on the importance of decent work. It was done by formulating a questionnaire and sending it to the membership of the EFC (Employers' Federation of Ceylon). Fifty organizations responded to this questionnaire from which information and data were gathered to prepare this paper.

This questionnaire specifically included the two main aspects of green jobs, viz., environmental sustainability and decent work. Environmental sustainability encompasses the attributes such as power utilization and related data, application of $3 \mathrm{R}$ principle (reduce, recycle and reuse potentials) in waste reduction, use of technologies that need less energy, raw material and other resources, proper house

*Correspondence: mahesh@civil.mrt.ac.lk

Tel: +94-011-2650567, Fax: +94-11-2651216

ISSN 2235-9370 Print / ISSN 2235-9362 Online (C2012 University of Sri Jayewardenepura 
keeping with cleaner production opportunities, potential for energy saving, reduction of greenhouse gases, reduction potential for fossil fuel usage, waste management and pollution reduction, ecosystem conservation etc., whereas decent work includes attributes such as wages, career prospects, job security, occupational health and safety as well as other working conditions, respectively.

The questionnaire was reviewed and updated with comments and information given by relevant authorities before finalization, which were then distributed to target organizations through EFC. In this survey, the private sector represents 92 per cent $(28$ private limited companies and 15 public limited companies) out of 50 organizations surveyed. Government sector contribution is about 6 per cent representing only three entities. As indicated by Economic and Social Statistics of Sri Lanka (2011) published by the Central Bank of Sri Lanka, contribution to the GDP by each sector was reckoned to be as follows: Agriculture 11.9 per cent, Industry 28.9 per cent and Services 57.3 per cent. Nevertheless, the organizations participated constituted 17 per cent in Agriculture, 40 per cent in Industry and 43 per cent in Services sectors, respectively.

\section{Environmental Sustainability towards Sri Lankan Economy through the Concept of Green Jobs}

The attributes that were considered in the survey to be pertinent for Sri Lankan economy are renewable energy, energy efficiency, green buildings and construction, conservation of natural resources including water, fisheries etc. forestry, afforestation/reforestation, environmentally friendly agriculture (pesticides free, water efficient, etc), clean transportation and fuels, mass transit, pollution prevention and control in manufacturing including cleaner production and good house-keeping and clean-up operations.

\subsection{Renewable Energy}

Due to the geo-climatic conditions, Sri Lanka is blessed with several forms of renewable energy resources. Some of them are widely used and developed to meet the energy demand of the country while others have the potential for development when technologies become feasible and economically viable for use. However, renewable energy has become one of the key areas in which about 5 per cent have made a positive change in this survey.

\subsubsection{Hydropower}

The hydroelectricity potential of the country has already been exploited to a major extent, a source that delivers comparatively low-cost electricity. Apart from the grid connected hydro power stations, there are small-scale hydro-power applications (mini and micro) in operation serving off-grid loads. According to the survey, off-grid electricity generation by using hydropower is dominated by the agriculture sector (10 organizations). This is mainly because of the fact that most of the organizations operating under agriculture sector are involved in tea production. The geo-climatic settings of the tea plantations are particularly conducive to harnessing hydro resources due to high rainfall in hilly areas throughout the year. In addition, there are two manufacturing entities that are involved in hydropower generation. Similarly, direct use of hydropower is also associated with the agriculture sector organizations as they produce electricity either by micro or mini hydropower plants.

\subsubsection{Biomass}

Large quantities of firewood and other biomass resources such as agriculture residues are used for cooking in rural households, despite the fact that they have access to grid electricity (Sri Lanka Sustainable Energy Authority, 2007). However, in the industry context, use of biomass to generate energy is somewhat lacking (only 2 organizations). Though biomass is a feasible option to produce energy, still more efforts are needed to convince the organizations to switch to biomass operated systems for their steam or electricity requirements. Though there is a huge potential for biomass energy particularly for the generation of electricity, supply of substrate material especially in the form of dendro-wood would be the 
main bottleneck as huge quantities (e.g., 1,000 acres for $1 \mathrm{MW}$ power production) are required. Sri Lanka does not have such large extents of land set aside exclusively for growing such plants (eg. Gliricidia sepium) but there are lands on which intercropping is possible.

\subsubsection{Solar Energy}

Solar energy is derived from solar radiation that has applications in space heating and cooling through solar architecture, day lighting, heating water, cooking, and high temperature processed heat for industrial purposes. As estimated in the solar resource map developed by the National Renewable Energy Laboratory (NREL) of the USA, over most parts of the flat dry zone in Sri Lanka, which accounts for two-thirds of the land area, solar radiation varies from $4.0-4.5 \mathrm{kWh} / \mathrm{m}^{2}$.day. Electricity generation using solar energy requires large areas (e.g., 40 acres per MW). However, the production of solar energy in the form of electricity seems to be lacking as this technology is reckoned to be comparatively expensive. It was evident from this survey too, that there are only 3 organizations (from each sector) who are involved in generating electricity using solar energy. In contrast, some are already engaged in utilizing energy in the form of electricity and more frequently hot water from solar panels. This trend seems to be on the rise as they may have understood the importance of reducing the use of fossil fuels for different activities. Surprisingly, some have thought of the 'net metering' concept where during day time electricity generated by solar panels will be utilized by the organization itself but during nighttime it will be connected to the grid so that what is stored in excess will be supplied to someone else. However, realization of such schemes may take some time and formal campaigns are of paramount importance in order to encourage organizations in the long run.

\subsubsection{Wind Energy}

Wind airflows can be used to run wind turbines thereby generating electricity. The power output of a turbine is a function of the cube of the wind speed, so as wind speed increases, power output increases dramatically. Areas where winds are stronger and more constant, such as offshore and high altitude sites are preferred locations for wind farms. According to the Wind Energy Resource Atlas of Sri Lanka developed by National Renewable Energy Laboratory (NREL) of the United States, there are nearly $5,000 \mathrm{~km}^{2}$ of windy areas with good-to-excellent wind resource potential in Sri Lanka. About $4,100 \mathrm{~km}^{2}$ of the total windy area is land and about $700 \mathrm{~km}^{2}$ is lagoon areas. The windy land represents about 6 per cent of the total land area of Sri Lanka. Using a conservative assumption of $5 \mathrm{MW}$ per $\mathrm{km}^{2}$, this windy land could support almost $20,000 \mathrm{MW}$ of potential installed capacity. Use of wind energy is also at a very poor level (only two organizations from the industry sector). This is probably due to the fact that the capital investment associated with wind energy is rather high and it requires substantial square kilometers of land.

\subsection{Energy Efficiency Measure}

It is remarkable to note that most organizations (about 30 organizations) those participated in this survey have paid great attention to energy efficiency measures. This improvement in the energy sector is partially attributable to the training and education on energy conservation and management, coordinating energy management activities through energy managers, introducing energy efficiency guidelines for building construction etc. It was also noted that organizations have had direct benefits by saving energy costs through improvement of efficiencies.

\subsubsection{Energy Audit}

Energy audit is commonly used to describe a broad spectrum of energy studies ranging from a quick walk-through of a facility to identify major problem areas to a comprehensive analysis of the implications of alternative energy efficiency measures sufficient to satisfy the financial criteria of sophisticated interventions. It provides energy solutions for saving the energy bill, improving energy efficiency by capturing energy wastages and to meet the demands of the green economy. There are about 
21 organizations those who have already got this audit done and have been enjoying reduced electricity bills by 10-20 per cent of energy savings.

\subsubsection{Good Housekeeping}

Housekeeping is one of the low cost/no cost for energy conservation opportunities which can be defined as an excellent starting point for improving the operations or day to day work. It is interesting to observe that most of the organizations (about 30) engaged in this survey have paid their attention to saving energy and/or increasing energy efficiency by means of good housekeeping measures. These measures can help save energy, reduce the cost of production and at the same time minimize losses of raw materials, minimize waste, conserve water and mitigate environmental impacts indicating a set of benefits.

\subsection{Green Buildings}

Green building design and construction is the opportunity to use natural resources more efficiently, while creating healthier environment, balancing energy-efficient, cost-effective and lowmaintenance products for construction needs. The Green Building Council of Sri Lanka (GBCSL) launched in November 2009 commits to developing a sustainable building industry for Sri Lanka. It will provide the necessary advice and know-how in the efforts of making buildings green. However, there were some organizations that have already received LEED certification from the U.S. Green Building Council. There are about 7 manufacturing industries and two entities from the Service sector that have already been involved in green building construction practices. It is clear that the Manufacturing sector is mainly involved in indoor climate control interventions as they directly benefit from such interventions particularly with the creation of a healthy environment to work comfortably within the factory premises. These scenarios undoubtedly increase the productivity and leads to gaining higher profit margins.

\subsection{Water Conservation}

Water conservation is relatively high in the industry sector as they consume a considerable amount of water for their industrial processes and also for cleaning up operations. In the agriculture sector, though watering is an essential component, many organizations now rely on rainwater. However, there are 8 organizations that employ water conservation practices in the Agriculture sector. There are 13 organizations from the industry sector who are involved in different water conservation methods. Unfortunately, the service sector (only 2 organizations) has not paid much attention to water conservation as it does not impact their day-to-day operations. Water conservation is also inhibited by the lower prices that Water Board has in offer and they do not reflect real production costs.

\subsubsection{Rainwater Harvesting}

Rainwater Harvesting (RWH) is a technique of arresting rainwater when it falls on to a shelter and storing it for subsequent use. Harvested rainwater can be utilized for several purposes including drinking, washing, gardening, etc. The National Policy on Rain Water Harvesting in Sri Lanka was officially launched on September 27, 2005. The main objective of the National RWH Policy is to ensure that the potential 'Cities of Tomorrow' apply rainwater harvesting broadly by the control of water near its source, in its pursuance of becoming 'Green Cities' in the future. Thus the demand on the water sources will be minimal if part or whole of the rainwater is utilized in an effective manner. Though rainwater harvesting is a good gesture to start off in conserving water, there are only 12 organizations who have taken an active part in such initiatives.

\subsubsection{Wastewater Reclamation/Recycling}

Recycling of wastewater has become an important aspect of water resources and environmental management policies. It ensures reliable alternative water resources, reduces pollution and achieves a 
more sustainable form of development. There are 12 organizations who have thought of it but implementation aspects seem to be poor yet.

\subsection{Reuse/recycling of Raw Materials}

'Reduce', 'Reuse', and 'Recycle' of materials are commonly known as the $3 \mathrm{R}$ principle. The 'Reduce' in 3R means the reduction of the amount of waste and rubbish produced by the organization. Reuse is the ability to use them once again may be for some other process or even for the same processes. Recycling is an array of processing by which used materials (waste) are converted to new products to prevent waste of potentially useful materials, reduce the consumption of fresh raw materials, reduce energy usage, and lower greenhouse gas emissions as compared to virgin production. There are ISO standards related to recycling such as ISO 15270:2008 for plastic waste and ISO 14001:2004 for environmental management control of recycling practice. In particular, the industry sector (15 organizations) and agriculture sector ( 9 organizations) are very keen on the $3 \mathrm{R}$ principle as it yields direct benefits to them. In service sector, there are 11 organizations involved in recycling/reuse of raw materials.

\subsection{Reforestation}

Reforestation is the natural or intentional restocking of existing forests and or woodlands that have been depleted, usually through deforestation. Reforestation can be used to improve the quality of human life by soaking up pollution and dust from the air, rebuild natural habitats and ecosystems thereby minimizing the global warming. In forestry related activities it is apparent that organizations that are in the Agriculture sector ( 9 organizations) have directly contributed to reforestation, afforestation, conservation of biodiversity, as it is part of their business. However contribution from industry sector (4 organizations) and services sector (3 organizations) are relatively low.

\subsection{Green Transport}

This refers to any means of transport with relatively insignificant adverse impacts on the environment, and includes walking and cycling, group transportation, mass transportation, pooling of vehicles, scheduled supply chain etc. while protecting urban transport systems that are fuel-efficient, space-saving and also promoting healthy lifestyles. Improving efficiency of a vehicle reduces its fuel consumption and emissions to atmosphere. A range of novel technologies and approaches would help create cleaner, more efficient vehicles, including light weight materials, advanced transmissions, batterydirect etc. There were quite a number of organizations (20 organizations) found involved in some of these schemes helping to reduce adverse impacts, particularly in relation to air pollution.

\subsection{Control and Prevention of Pollution}

In an attempt to abate the scenarios of pollution, the amounts of pollutants generated were not quantified by most organizations. There are considerable numbers of organizations (16 organizations) producing industrial wastewater and employ different wastewater treatment methods prior to discharge the effluents to the environment. However, sustainability of such technologies is questionable as hardly any $3 \mathrm{R}$ principles are applied. Therefore, it is imperative to note that pollution prevention efforts need to pay more attention on environmentally friendly and sustainable practices.

\subsubsection{Air Quality}

Air pollution is a change in the physical, chemical and biological characteristics of air that causes adverse effects on humans and other organisms. However, in the present survey, the amount of pollutants generated was not quantified. However the types of air pollutants emanated by organizations and their mitigation techniques were recorded. Only a very few organization ( 8 organizations) have an idea of what 
types of pollutants that they emit into atmosphere as a result of their business activities. Awareness campaigns are therefore of utmost importance.

\subsubsection{Wastewater}

The main sources of water pollution are domestic, urban and municipal wastes (including both sewerage and solid waste), agro-chemicals (such as pesticides, fertilizers and herbicides), industrial effluents (including chemicals, detergents, heavy metals and oils) and marine and shipping waste (including oil spills, chemicals and ballast water) etc. There are separate standards that have been set for potable water (drinking water) and effluents (wastewaters that are discharged from industries and sewerage treatment plants). The standards for effluent discharge into water sources have been defined in relation to the specific places of discharge (irrigation land, marine and coastal areas, surface waters), types of effluents (domestic or industrial), and type of industry (rubber, textiles, tanning, palm oil and coconut kernel etc). Any standard for a specific industry overrides the general standards. In this survey, it was seen that some organizations (about 16 organizations) produce industrial wastewater and they employ different wastewater treatment methods prior to discharge to the environment.

\subsubsection{Hazardous Waste}

Hazardous waste is waste material that is reactive, toxic, corrosive or otherwise poses a hazard to human health and environment. Hazardous waste needs special collection and disposal. Toxic and hazardous waste is generated mainly in the industrial and medical sectors and is being generated in increased quantities. Hazardous waste includes heavy metals, oil, agrochemicals, paints, varnish and asbestos waste etc. Thirteen organizations are found to generate hazardous materials and employ different methods of management. Some hand the waste over to a competent entity capable of handling and processing the hazardous waste at a price, however, there are others who are clueless of safe disposal methods. Hence it is apparent that handling hazardous waste is also an appropriate topic on which training must be organized.

\section{Decent Work for Sri Lankan Economy through the Concept of Green Jobs}

The definition of green jobs focuses not only on the environmental aspects of a job. Green jobs also need to be decent jobs with concerns including wages, career prospects, job security, occupational health and safety as well as other working conditions. People's livelihoods, rights, and sense of dignity are integral to their jobs; jobs need to provide equal hope for the environment and the jobholder. A job which is exploitative or harmful, or fails to pay a living wage cannot be called 'green'. Preferably, the future of employment will be more respectful and protective while caring for the natural environment and workers' health, basic needs, and rights of employees.

In this survey, environmental policy, HR/HRD policy, policy for disabled, gender equity policy, policy for HIV/AIDS etc. were considered as policies in existence in order to support employees. In addition, transport, medical, overtime, maternity, worker participation in decision making, equal opportunity employment, procedure for grievances/and arbitration are also included.

\subsection{Environmental Policy}

Environmental policy is any action deliberately taken to manage human activities with a view to preventing, reducing or mitigating harmful effects on nature and natural resources, and ensuring that human intervention to the environment does not have any harmful effects on the community. In this survey, however, the adoption of environmental policies in each sector (Agriculture - 6 organizations, Industry-7 organizations and Services-6 organizations) is relatively low. Nevertheless, some of the organizations have already ratified internationally recognized sustainability standards, which are considered essential requirements of an environment related policy. 


\subsection{Human Resource Policies}

Human resource policies are systems of codified decisions, established by an organization, to support administrative personnel functions, performance management, employee relations and resource planning. Each organization has a different set of circumstances, and based on them, develops an individual set of human resource policies. Almost all organizations (44 organizations) have a written policy on Human Resource Management.

\subsection{Gender Equality Policy}

The international definition of gender equality is "that all human beings are free to develop their personal abilities and make choices without the limitations set by strict gender roles; that the different behavior, aspirations and needs of women and men are equally considered, valued and favored". The implementation of such a policy is relatively a low priority (only 11 organizations) as most of the organizations mentioned that they do care about the worker's potential and capability to work regardless of gender alluding to a gender neutral approach in the workplace.

\subsection{HIV/AIDS Policy}

HIV/AIDS is a major development crisis that affects all sectors. During the last two decades the HIV/AIDS epidemic has spread relentlessly affecting people in all walks of life and decimating the most productive segments of the population particularly women and men between the ages of 20 and 49 years. In this present survey only 8 responses were recorded.

\subsection{Worker's Welfare Policy}

Welfare includes anything that is done for the comfort and improvement of employees and is provided over and above the wages, but not as a matter of right. Welfare helps in keeping the morale and motivation of the employees high so as to retain the employees for longer duration. Employee welfare includes addressing challenges in working conditions, creation of industrial harmony through infrastructure for health, industrial relations and insurance against disease, accident and unemployment for the workers and their families. There are about 20 organizations that have come up with welfare policies and the managements of these organizations have such policies and employees are benefitting from it.

\section{6. $E P F / E T F$}

All the organizations (50) engaged in this survey have contributed to these schemes which are a statutory requirement.

\subsection{Career Development Opportunity}

Career development opportunity seems to be very prominent in each sector as 10 organizations from Agriculture sector, 20 organizations from Industry sector and 19 organizations from Services sector are offering career development opportunities for their employees.

\subsection{Life and Health Insurance}

Life and health insurance becomes vital as such schemes may help to facilitate proper health care for the employees. 44 organizations have implemented such schemes successfully.

\subsection{Profit sharing Scheme}

Sharing of profits among the workers seems to be quite low as 20 organizations from all sectors have introduced such schemes to the employees. 


\subsection{Bonus Scheme}

Bonus schemes seem to be quite popular as 10 organizations from Agriculture sector, 17 organizations from Industry sector, and 17 organizations from Services sector are involved in bonus schemes.

\section{Gaps in Green jobs: Sri Lankan Context}

This analysis highlights the existing practices of green jobs and deficits in the above-mentioned sectors that included 50 organizations that provided information related to green jobs. The two pillars of green jobs were considered when analyzing the gaps, viz., Environmental Sustainability and Decent Work. A number of issues in this context were raised and following is the list of issues raised and questions set in to gather more information.

Question 1: Does your business or organization currently have any green jobs initiatives?

This question was raised to gather current information on any green jobs initiatives that the organization has already initiated, and/or planning to initiate. Out of the 50 local organizations participated in the survey, only 14 indicated that their businesses have 'green' jobs initiatives; the rest either skipped the question without answering by leaving the section blank or stated 'no'. Nevertheless, some organizations in the Industry sector seemed to have well-understood the green concept and even have achieved international sustainable standards. It is encouraging to note that some organizations in the Agriculture sectors have already initiated and incorporated green culture into their business strategies. At the same time, it is disappointing to note that the Services sector is far behind in green job initiatives and implementing sustainability initiatives.

Question 2: What do you think is preventing your organization (or in being less committed to) in implementing green initiatives?

This question was raised to identify any constraints in implementing any green imitative(s). For the majority, the cost factor seemed to be the highest concern in implementing green job initiatives and adopting green technologies. In addition, the longer period for return on investments, lack of skilled staff and knowledge etc. were also identified. Some organizations in the Industry sector have taken the lead in making the jobs greener and taken the leadership of 'going green'. The Services sector, on the contrary, were lagging behind in adopting green practices assuming that green business is something that is not related to their day-to-day activities that they are involved in.

Question 3: What factors (green jobs related) do limit the growth of your business? Please comment on what you feel can be done at the national policy level to assist growth in this sector.

This question was raised to identify limitation of the growth of business activities that can be directly related to any green job-related factors. The organizations who took part in the survey believe that national level policies need to be strengthened and/or implemented in order to help and assist organizations to move forward in the environment friendly business concepts and policies to compensate them and also provide incentives for organizations which have already implemented green initiatives. National level policies are also needed to concentrate more on environmentally friendly alternatives for energy generation (electricity), by so ensuring that the organizations that opt for such greener options and the country as a whole will be benefitted in the long run. Moreover, at the national policy level, green jobs must be an integral part of the routine day-to-day activities, standardized policies and practices with objective parameters to gauge the performance and a periodic evaluation to measure the performance, and a rating system to recognize star performers. 
Question 4: What do you think is the best strength of your organization in implementing green job initiatives?

This question was raised to identify positive attributes of an organization for successful implementation of green job initiatives. The organizations operating at a large scale, especially in the Industry and Agriculture sectors are moving onto more environmentally friendly technologies and sustainability and green initiatives because such plans may open up with opportunities that are competitively advantageous for them. Moreover, some tools like lean manufacturing have increased the efficiency and productivity of the manufacturing processes. The commitment of top management is indicated as the best strength in these organizations in implementing green job initiatives.

The gap analysis manifested that most job positions require 'on the job training' to enhance 'soft skills' and basic skills but do not necessarily require advanced green knowledge. The soft skills essentially uplift dependability and reliability, initiative, and interpersonal skills of employees. Green knowledge is more important for managers and small business owners who establish 'green' procedures and provide 'on the job training' for their employees. Hence the component of training particularly on decent work at different levels is of utmost importance for the establishment of green jobs in Sri Lanka.

Nevertheless, it is apparent from this study that the present status of green jobs in Sri Lanka is less impressive, hence a series of gaps have to be addressed. Although certain organizations have embraced environmental technologies that are reckoned to be green, adoption of decent work conditions among their employees is questionable. This may be due to the fact that sustainable technologies pay them back tangible benefits in a comparatively shorter period of time but the benefits from decent work seem to be intangible. This disparity could be rectified through well-structured awareness programmes for all levels of employees thereby creating a healthy bank of green jobs.

\section{Training Needs for Effective Green Jobs}

Having analyzed the questionnaires it was evident that Sri Lankan organizations need comprehensive training packages in order to create green jobs in their respective sectors. As the green job concept as a business case is rather new to Sri Lanka organizations have not initiated necessary action to implement the green jobs. Sustainable enterprises and industries would be the key to survival with ever increasing fossil fuel prices and in this context adoption of green jobs would be an added advantage hence it is of paramount importance to move towards a green job culture even now. To implement sustainable enterprises and industries effectively, employees must be trained at every level of their hierarchy. At present new frontier technologies that are reckoned to be green are imperative for well-performing enterprises. When interviewed, it was clear that most of them showed reluctance in adopting new green technology as they were not fully informed of its positive impact on the enterprise. A formally developed well-structured course on green jobs is therefore essential in order to fill the knowledge and technical skills gap.

\subsection{Level of Training Needed for Effective Green Jobs}

Positive attitudes towards effective green jobs by top-management are of utmost importance and their initiatives are essential to initiate the creation of green jobs. However knowledge on green jobs by the top-management seems to be varied but there remain misconceptions. Hence a workshop for the top management would help resolve these issues and their mindset could be adjusted in a positive manner so that greener jobs could be created within enterprises and industries. At the middle level, employees were found to contribute much in various ways to decision making on creating green business but their knowhow seems insufficient due to a lack of formal training. There were a few middle level employees who have received foreign training and a few others who have received training locally. 
Table 1: Contribution by sectors for different attributes of green jobs

\begin{tabular}{|c|c|c|c|c|c|c|c|c|}
\hline \multirow{2}{*}{$\begin{array}{l}\text { Number of } \\
\text { Organizations }\end{array}$} & \multicolumn{2}{|c|}{ Agriculture } & \multicolumn{2}{|l|}{ Industry } & \multicolumn{2}{|c|}{ Services } & \multicolumn{2}{|c|}{ Total } \\
\hline & \multicolumn{2}{|l|}{12} & \multicolumn{2}{|l|}{28} & \multicolumn{2}{|c|}{10} & \multicolumn{2}{|c|}{50} \\
\hline Attribute & Number & $\begin{array}{l}\% \text { of } \\
\text { total }\end{array}$ & Number & $\begin{array}{l}\% \text { of } \\
\text { total }\end{array}$ & Number & $\begin{array}{l}\% \text { of } \\
\text { total }\end{array}$ & Number & $\begin{array}{l}\% \text { of } \\
\text { total }\end{array}$ \\
\hline \multicolumn{9}{|c|}{ Environmental Sustainability } \\
\hline \multicolumn{9}{|l|}{ Renewable Energy } \\
\hline Hydro & 10 & $20 \%$ & 2 & $4 \%$ & 0 & $0 \%$ & 12 & $24 \%$ \\
\hline Biomass & 1 & $2 \%$ & 1 & $2 \%$ & 0 & $0 \%$ & 2 & $4 \%$ \\
\hline Wind & 0 & $0 \%$ & 2 & $4 \%$ & 0 & $0 \%$ & 2 & $4 \%$ \\
\hline Solar & 1 & $2 \%$ & 1 & $2 \%$ & 1 & $2 \%$ & 3 & $6 \%$ \\
\hline Energy Efficiency & 8 & $16 \%$ & 18 & $36 \%$ & 4 & $8 \%$ & 30 & $60 \%$ \\
\hline $\begin{array}{l}\text { Energy Audit } \\
\text { Good House }\end{array}$ & 5 & $10 \%$ & 13 & $26 \%$ & 4 & $8 \%$ & 22 & $44 \%$ \\
\hline Keeping & 5 & $10 \%$ & 13 & $26 \%$ & 7 & $14 \%$ & 25 & $50 \%$ \\
\hline Green Buildings & 2 & $4 \%$ & 7 & $14 \%$ & 5 & $10 \%$ & 14 & $28 \%$ \\
\hline Water conservation & 8 & $16 \%$ & 13 & $26 \%$ & 2 & $4 \%$ & 23 & $46 \%$ \\
\hline $\begin{array}{l}\text { Recycling of raw } \\
\text { materials }\end{array}$ & 9 & $18 \%$ & 15 & $30 \%$ & 11 & $22 \%$ & 35 & $70 \%$ \\
\hline Reforestation & 9 & $18 \%$ & 4 & $8 \%$ & 3 & $6 \%$ & 16 & $32 \%$ \\
\hline $\begin{array}{l}\text { Green Transportation } \\
\text { Control and } \\
\text { Prevention of } \\
\text { Pollution }\end{array}$ & 2 & $4 \%$ & 13 & $26 \%$ & 5 & $10 \%$ & 20 & $40 \%$ \\
\hline Air quality & 0 & $0 \%$ & 6 & $12 \%$ & 2 & $4 \%$ & 8 & $16 \%$ \\
\hline Wastewater & 2 & $4 \%$ & 10 & $20 \%$ & 4 & $8 \%$ & 16 & $32 \%$ \\
\hline Hazardous waste & 2 & $4 \%$ & 8 & $16 \%$ & 3 & $6 \%$ & 13 & $26 \%$ \\
\hline \multicolumn{9}{|l|}{ Decent Work } \\
\hline Environment policy & 6 & $12 \%$ & 7 & $14 \%$ & 6 & $12 \%$ & 19 & $38 \%$ \\
\hline HR Policy & 10 & $20 \%$ & 15 & $30 \%$ & 19 & $38 \%$ & 44 & $88 \%$ \\
\hline Gender Equity & 8 & $16 \%$ & 11 & $22 \%$ & 9 & $18 \%$ & 28 & $56 \%$ \\
\hline $\begin{array}{l}\text { HIV/AIDS policy } \\
\text { Workers Welfare }\end{array}$ & 2 & $4 \%$ & 2 & $4 \%$ & 4 & $8 \%$ & 8 & $16 \%$ \\
\hline Policy & 10 & $20 \%$ & 18 & $36 \%$ & 19 & $38 \%$ & 47 & $94 \%$ \\
\hline EPF/ETF & 12 & $24 \%$ & 19 & $38 \%$ & 19 & $38 \%$ & 50 & $100 \%$ \\
\hline $\begin{array}{l}\text { Career development } \\
\text { Life \& Health }\end{array}$ & 10 & $20 \%$ & 20 & $40 \%$ & 19 & $38 \%$ & 49 & $98 \%$ \\
\hline $\begin{array}{c}\text { Insurance } \\
\text { Profit sharing }\end{array}$ & 9 & $18 \%$ & 19 & $38 \%$ & 16 & $32 \%$ & 44 & $88 \%$ \\
\hline scheme & 8 & $16 \%$ & 5 & $10 \%$ & 7 & $14 \%$ & 20 & $40 \%$ \\
\hline Bonus scheme & 10 & $20 \%$ & 17 & $34 \%$ & 17 & $34 \%$ & 44 & $88 \%$ \\
\hline
\end{tabular}




\section{Conclusions}

Though EFC has a large number of members (about 500) only 50 members responded to the questionnaire. The questionnaire consisted of two main sections namely sustainable green technologies and initiatives and decent work, respectively. The Table 1 summarized the contribution of each sector for different attributes of green jobs.

In this survey, in terms of environmental sustainability, the contribution from Industry sector is relatively high with compared to Agriculture and Services sectors (Table 1). However, some essential components of environmental sustainability such as switching to renewable energy (biomass, solar) are rather low.

Measures to increase energy efficiency in terms of energy audits and/or good housekeeping seem to be attractive for every sector as it significantly reduces the cost of electricity. Thus green building concept has been recently popularized among organizations with involvement of 28 per cent in all sectors. Water conservation among organizations needs to be increased as water resources become scarce. Recycling of raw materials (e.g., paper) is practiced widely and total contribution is about 70 per cent for all sectors.

The decent work component seems to be relatively strong in terms of statutory attributes such as $\mathrm{EPF} / \mathrm{ETF}$, health and safety issues, maternity and overtime provisions. In addition, some other benefits such as transport, insurance and bonus schemes are also provided for employees though they are not statutory requirements. It is interesting to note that career development is considered important by almost all organizations. However, some essential attributes pertaining to decent work such as having a policy for HIV.AIDS, gender equity are still lacking. Moreover, according to the ILO definition, some essential components of decent work such as freedom of association, abolition of forced or compulsory labour, elimination of discrimination in respect of employment and occupation etc. could not be grasped properly through the questionnaire.

In order to see a positive growth in green jobs, organizations must foresee the benefits of green jobs and they should explore the possibility of moving towards becoming greener businesses by catering to green needs and opportunities. In summary it is apparent that most of the organizations stick to the mandatory attributes with great success but other attributes that are of paramount for green jobs are yet to be embraced at large. At least a few of these organizations have perceived the importance of green jobs in the context of retention of good work force among them. In future what remains within the sustainable economy reflects a large number of green jobs creations through practices of more and more environmental sustainable initiatives with decent work embedded in them.

\section{Recommendations}

Initially, data that have been collected would be published for the purpose of dissemination so that there is better access to the findings of this study. Secondly, to create a database within the EFC from which the membership could make referrals for advice, and services in relation to green jobs, concerted efforts should be taken collectively by all stakeholders. It is also recommended that a monitoring mechanism to facilitate and support greening jobs within the EFC membership is established through EFC's green team with technical support from the ILO. A green jobs policy and a set of guidelines on green jobs for organizations are recommended to ensure sustainability for and amongst relevant stakeholders. Finally, a database on the types of green jobs in Sri Lanka could be prepared by EFC to be distributed among enterprises and industries to facilitate a just transition through sharing of knowledge and exchange of information. 


\section{Acknowledgements}

We wish to thank Mrs. Shyama Salgado, ILO representative, for all the assistance and encouragement given to us in conducting this survey and the EFC Green Team headed by Ms. Thamali Senanayake for all their efforts in bringing about a successful completion of a survey on "Green Jobs" amongst employers in Sri Lanka.

\section{References}

Bulletin of Labour Force Statistics of Sri Lanka, Department of Census \& Statistics, Issue No.55, ISSN 1391- 3050, Department of Census \& Statistics, Colombo.

Central Bank of Sri Lanka, 2011, Economic and Social Statistics of Sri Lanka, ISBN 978 - 955 - 575 212 - 1, Central Bank of Sri Lanka, Colombo.

Green Building Council Sri Lanka, 2010, GREENSL® Rating System for Built Environment. Green Building Council, Sri Lanka.

International Labour Organization, 2007, International Labour Conference on conclusions concerning the promotion of sustainable enterprises, ISBN 978-92-2-120131-1 (print), ISBN 978-92-2-120132-8 (web pdf), International Labour Office, Geneva.

Judges and Environmental Law, A Handbook for Sri Lankan Judiciary, 2009, ISBN 978-955-8302-03-3. Environmental Foundation Limited, Sri Lanka.

Ministry of Environment, 2011, National Green Reporting System of Sri Lanka, Reporting Guidelines, Ministry of Environment, Sri Lanka.

Sri Lanka Sustainable Energy Authority, 2007, Sri Lanka Energy Balance: An Analysis of Energy Sector Performance, Sri Lanka Sustainable Energy Authority, Sri Lanka.

United Nations Environment Programme, 2008, Green Jobs: Towards decent work in a sustainable, lowcarbon world, ISBN: 978-92-807-2940-5. United Nations Environment Programme (UNEP), Nairobi. 